occurs. The addition of onions, whether fried or boiled, not only prevented this reduction but also caused a marked increase. Recalcified clotting-times, thrombotests, and cholesterol and fibrinogen levels were not significantly changed (Table IV).

TABLE IV.-Mean Values of Recalcified Clotting-times (R.C.T.) Thrombotest, Cholesterol, and Fibrinogen With and Without Fried Onions (22 Patients)

\begin{tabular}{|c|c|c|c|c|c|c|}
\hline & \multicolumn{3}{|c|}{$\begin{array}{l}\text { Ordinary } \\
\text { Breakfast }\end{array}$} & \multicolumn{3}{|c|}{$\begin{array}{c}\text { Ordinary Breakfast } \\
\text { Plus Onions }\end{array}$} \\
\hline & 9 a.m. & 11.30 a.m. & 12.30 p.m. & 9 a.m. & 11.30 a.m. & 12.30 p.m. \\
\hline $\begin{array}{l}\text { R.C.T. (seconds) } \\
\text { Thrombotest (\%) }\end{array}$ & $\begin{array}{l}87 \cdot 8 \\
80 \cdot 1\end{array}$ & $\begin{array}{l}88 \cdot 4 \\
81 \cdot 2\end{array}$ & $90 \cdot 2$ & $\begin{array}{l}91.9 \\
82.2\end{array}$ & $\begin{array}{l}92.3 \\
81.8\end{array}$ & $92 \cdot 1$ \\
\hline Fibrinogen $\left\{\begin{array}{l}\mathbf{D} \\
\mathbf{E} \\
\mathbf{F} \\
\mathbf{G} \\
\mathbf{H}\end{array}\right.$ & $\begin{array}{c}220 \cdot 7 \\
2 \\
6 \\
5 \\
8 \\
1\end{array}$ & $\begin{array}{l}-3 \\
3 \\
9 \\
5 \\
2\end{array}$ & $\begin{array}{c}216 \cdot 7 \\
3 \\
2 \\
8 \\
5 \\
4\end{array}$ & $\begin{array}{c}212 \cdot 5 \\
2 \\
3 \\
7 \\
8 \\
2\end{array}$ & $\begin{array}{r}- \\
0 \\
5 \\
5 \\
10 \\
2\end{array}$ & $\begin{array}{c}219 \cdot 8 \\
2 \\
1 \\
7 \\
4 \\
8\end{array}$ \\
\hline
\end{tabular}

\section{Discussion}

The results confirm the findings of Gupta et al. (1966) that the addition of onions to a fat-enriched meal not only prewents the expected reduction in fibrinolytic activity caused by such a diet but actually promotes significant increase of it in every patient $(P<0.001)$. The results also indicate that the factor responsible is not only heat-stable but probably not watersoluble.

Undoubtedly there is a need for some substance which will have this effect on fibrinolytic activity in relation to fatty foods. We already have adequate agents for the prevention and treatment of excessive fibrinolytic activity-for example, aminocaproic acid, para-aminomethylbenzoic acid, and Trasylol (Okamoto and Okamoto, 1962; New Engl. F. Med., 1965; Menon, 1967b). Most of the agents potent in enhancing the fibrinolytic activity are, however, antigenic (for example, streptokinase), very expensive (for example, urokinase), or transient in effect (for example, nicotinic acid), and in any case only effective parenterally (Tillet et al., 1955; Weiner ct al., 1958 ; Celander and Guest, 1960 ; Menon, 1966b). Research has been carried out in the hope of discovering a cheap nonantigenic drug (Menon, 1967c). Fearnley et al. (1967) investigated the oral antidiabetic group of drugs, sulphonylureas and diguanides, and found metformin to be the most effective as well as the best tolerated.

Onions are known to be composed of essential oils, allypropyl, disulphide, catechols, thioproprione aldehyde, protocatechuic acid, thiocyanates, as well as some calcium, phosphorus, iron and vitamins (Wealth of India, 1948 ; Paech and Tracey, 1955 ; Chopra et al., 1956). Whether the increased fibrinolytic activity in the blood is caused by one of these or by a hitherto unknown component of the onion has not yet been established, though investigations are in progress to clarify this.

Our thanks are due to Professor A. G. Heppleston and Professor A. L. Latner for assistance with the study, to Mrs. D. Weightman for statistical help, and to Sister R. Watkins and Sister M. J. O. Freeman for their careful supervision of the diet. We are also indebted to Mr. Alan Martin for technical assistance and to Mrs. M. Jackson, our Editor of Research Publications, for invaluable editorial help.

\section{REFERENCES}

Billimoria, J. D., Drysdale, J., James, D. C. O., and Maclagan, N. F. (1959). Lancet, 2, 471.

Celander, D. R. and Guest, M M (1960). Amer, 7. Cardiol., 6, 409.

Chopra, R. N., Nayar, S. L., and Chopra, I. C. (1956). G̈lossary of Indian Plants, p. 11. New Delhi.

Fearnley, G. R., Chakrabarti, R., Hocking, E. D., and Evans, J. F. (1967). Lancet, 2,1008.

Greig, H. B. 'W., and Runde, I. A. (1957). Lancet, 2, 461.

Gupta, N. N., Mehrotra, R. M. L., and Sircar, A. R. (1966). Indian f. med. Res., 54, 48.

Mehrotra, R. M. L., Gupta, N. N., and Mittal, S. P. (1966). Indian $\mathcal{F}$. med. Res., 54, 54.

Menon, I. S. (19668). Lancet, 2, 1365.

Menon, I. S. (1966b). Brit. F. clin. Pract., 20, 561

Menon, I. S. (1967a). Lab. Pract., 16, 469.

Menon, I. S. (1967a). Lab. Pract., 16, 469.

Menon, I. S. (1967b). Brit. F. clin. Pract., 21,

Menon, I. S. (1967c). Lab. Pract., 16, 1096.

Menon, I. S., and Dewar, H. A. (1967). Brit. med. f., 2, 613 .

Moser, K. M., and Haijar, G. C. (1966). Amer. F. med. Sci., 251, 536.

New Engl. F. Med., 1965, 273, 336

Okamoto, S., and Ökamoto, U. (1962). Keio f. Med., 11, 105.

Paech, K., and Tracey, M. V. (editors) (1955). Modern Methods in Plant Analysis, p. 714. Berlin.

Schneider, C. L. (1952). Amer. 7. Obstet. Gynec., 64, 141.

Tillet, W. S. Johnson, A. J., and McCarty, W. R. (1955). $\dot{f}$. clin. Invest., 34, 169.

von Kaulla, K. N. (1963). Chemistry of Thrombolysis : Human Fibrinolyric Enzymes, p. 79. Springfield, Illinois.

Wealth of India, 1948, 1, 56. New Delhi.

Weiner, M., Redisch, W., and Steele, J. M. (1958). Proc. Soc. exp. Biol. (N.Y.), 98, 755 .

\title{
Experience with a Hepatitis-free Plasma Protein Solution
}

\author{
A. J. SALSBURY,* M.D. ; M. BROZOVICH,* M.D.
}

\footnotetext{
Gummary : Clinical experience with a $4.3 \%$ solution of $S$ plasma protein treated to render it free of the agent of serum hepatitis is satisfactory. Sixty-seven transfusions of $400 \mathrm{ml}$. of the commercial preparation were given to 33 patients ( 25 with acute blood loss, 4 with severe burns, and 4 with hypoproteinaemia secondary to hepatic or renal disease).

The solution was clinically as effective as reconstituted dried plasma in expanding plasma volume and in replacing serum protein lost in burns. Adverse effects were mild pyrexial reactions in one case and facial flushing in another. No cases of serum hepatitis occurred.

The solution is available for immediate use, it can be kept at room temperature, and, as it does not cause rouleaux formation, it can be given before blood is taken for grouping and cross-matching.
}

\section{Introduction}

The value of reconstituted dried plasma in the restoration of blood volume by transfusion is well proved. Unfortunately such transfusion carries a slight but definite risk of transmission of disease, serum hepatitis presenting the greatest problem. The incidence of serum hepatitis after transfusion of plasma has been estimated as less than $1 \%$ in "small-pool" plasma (Medical Research Council, 1954) and as high as $18 \%$ in "large-pool" plasma (Morgan and Williamson, 1943).

It was largely because of the risk of serum hepatitis in transfusion of plasma that synthetic plasma expanders, such as the $\delta$ dextrans, were developed. Certain plasma fractions, particularly albumin, are also thought to be free from the agent causing serum hepatitis (Paine and Janeway, 1952).

* Department of Haematology, St. Bartholomew's Hospital, London
E.C.1. 作 
Heating plasma to $60^{\circ} \mathrm{C}$. for 10 hours inactivates the agent of serum hepatitis (Murray and Diefenbach, 1953), but such heating results in the denaturation of some globulin (Murray, Diefenbach, Geller, Leone, and Ratner, 1955). However, if the heat-labile globulin is first removed, a plasma protein solution stable when heated at $60^{\circ} \mathrm{C}$. for 10 hours is produced. The globulin can be fractionated out by alcohol (Cohn et al., 1946), by precipitation with polyphosphate (Nitschmann and Kistler, 1954 ; Nitschmann, Kistler, Renfer, Hässig, and Joss, 1956 ; Nitschmann, Rickli, and Kistler, 1959), or by ammonium sulphate precipitation in the presence of fatty acids (Auerswald and Eibl, 1955; Auerswald, Doleschel, and Szegvári, 1959).

A hepatitis-free plasma protein solution produced by the method of Auerswald and Eibl (1955) has been used on a large scale in Austria and Germany for several years (Auerswald and Doleschel, 1959). It is available in this country as a $4.3 \%$ solution containing approximately $84 \%$ albumin and most of the $\alpha-$ and $\beta$-globulins, these being heat-stable, but not $\gamma$-globulin. The solution is stable at room temperature for five years, and is a commercial preparation marketed in this country by Serological Products Ltd. It is prepared by the Austrian Institute for Haemoderivate, Vienna. The present cost is $£ 1414 \mathrm{~s}$. per bottle. This paper gives the results of our experience with the material over a period of 18 months.

\section{Procedure}

Thirty-three patients received $67400-\mathrm{ml}$. transfusions of $4.3 \%$ plasma protein solution : 25 required restoration of blood volume following acute blood loss, 4 suffered from burns, and 4 had developed hypoproteinaemia secondary to hepatic or renal disease.

The reason for transfusion and the period of time over which the plasma protein was given were noted in each instance, and clinical benefit to the patient was assessed by the following criteria: (1) rise in blood pressure (pretransfusion and post-transfusion values); (2) fall in pulse rate (pretransfusion and post-transfusion values); (3) general improvement in clinical condition of the patient-for example, disappearance of pallor, increase in temperature of extremities in cases of blood loss and burns, and reduction of oedema in cases of hypoproteinaemia; and (4) rise in serum albumin. Any adverse reactions to transfusion, such as rashes or pyrexia, were noted.

A follow-up of every patient alive six months after transfusion was made to assess whether serum hepatitis had developed.

\section{Results}

Acute Blood Loss.-The 25 patients suffering from acute blood loss received $33400-\mathrm{ml}$. transfusions (see Table). Indications for transfusion were oligaemic shock in 22 , sudden fall in blood pressure in two, and sudden heavy bleeding during surgical exploration in one. In 15 of these patients both the systolic and the diastolic pressure levels rose during transfusion; in six the systolic level rose but not the diastolic; and in one patient the diastolic rose but not the systolic. Blood pressure was unaffected by transfusion in three patients. Clinical improvement, as judged by the criteria listed above, occurred in 21 of the 22 patients whose blood pressure increased. Of the three whose blood pressure was unaffected by transfusion one showed clinical improvement and two did not; one of the latter subsequently died in spite of massive blood transfusions.

Of the 22 patients whose blood pressure increased the pulse rate fell in 19, was unchanged in 1 , and rose in 2 . The pulse rate fell in two of the three showing no increase in blood pressure after transfusion and rose in one (this was the patient who subsequently died). To 21 patients subsequent blood transfusion was given. One patient was also given blood before transfusion of plasma protein solution.

Severe Burns.-Four patients suffering from severe burns received $19400-\mathrm{ml}$. transfusions of plasma protein solution (see Table). Transfusion was spread over a period of four to seven days, no more than $800 \mathrm{ml}$. being given at one time. In every case the clinical effect was good and the serum albumin level rose.

Hypoproteinaemia.-Two patients suffering from hypoproteinaemia secondary to chronic renal disease and two patients with cirrhosis of the liver received $15400-\mathrm{ml}$. transfusions of plasma protein solution (see Table). One case of cirrhosis showed a considerable reduction of oedema; the other showed no improvement and died three weeks later. In both patients the serum albumin level rose during transfusion.

Serum albumin levels of the two patients with renal disease also rose. One showed a moderate reduction of oedema; the other was clinically unaffected by transfusion and died three days later.

\section{Adverse Effects of Transfusion}

One patient suffering from burns was given the plasma protein solution on four occasions. On two of these his temperature remained normal, but it rose to $99.2^{\circ} \mathrm{F}$. $\left(37.3^{\circ} \mathrm{C}\right.$.) on one occasion and to $99.8^{\circ} \mathrm{F}$. $\left(37.7^{\circ} \mathrm{C}\right.$.) on another. One patient with postpartum haemorrhage developed slight facial flushing during transfusion, but showed no other ill effects and maintained a normal temperature. No instances of urticarial reactions, angioneurotic oedema, bronchial spasm, or delayed hypersensitivity were encountered in this series.

The 30 patients alive six months after transfusion were checked for evidence of serum hepatitis. No cases of serum hepatitis were found.

\section{Discussion}

Since there is inevitably some delay in the grouping and cross-matching of blood, the value of other transfusion materials capable of combating oligaemic shock is widely accepted. Of these materials reconstituted dried plasma carries the hazard of serum hepatitis and the majority of dextrans cause rouleaux formation and possible interference with transfusion serology. The plasma protein solution is free from such drawbacks.

\section{Beneficial Effects}

The effects of a transfusion material for the restoration of blood volume are difficult to assess. In this study indirect factors were used in assessing the response to transfusion following acute blood loss. These factors comprised rise in blood pressure, fall in pulse rate, and general improvement in the clinical condition of the patient as described above. The transfusion of plasma protein solution produced an improvement as measured by one or more of these factors in 23 out of 25 patients with acute blood loss. Of the two patients unaffected by transfusion one was moribund. Published work on the therapeutic effect of plasma transfusion is somewhat scanty. However, stored plasma (Hillman, 1964) appears to be more effective than fresh plasma (Hutchison, Freedman, Richards, and Burgen, 1960). In the present series transfusion of plasma protein solution was at least equivalent in its therapeutic effect to an equivalent volume of reconstituted dried plasma.

The value of transfusion of plasma protein solution was more easily assessed in patients suffering from burns. Two criteria were used: increase in serum albumin levels after transfusion and clinical improvement. Transfusion of plasma protein solution in such cases yielded excellent results : not only was hypoproteinaemia due to loss of serum from burned 
Details of Cases

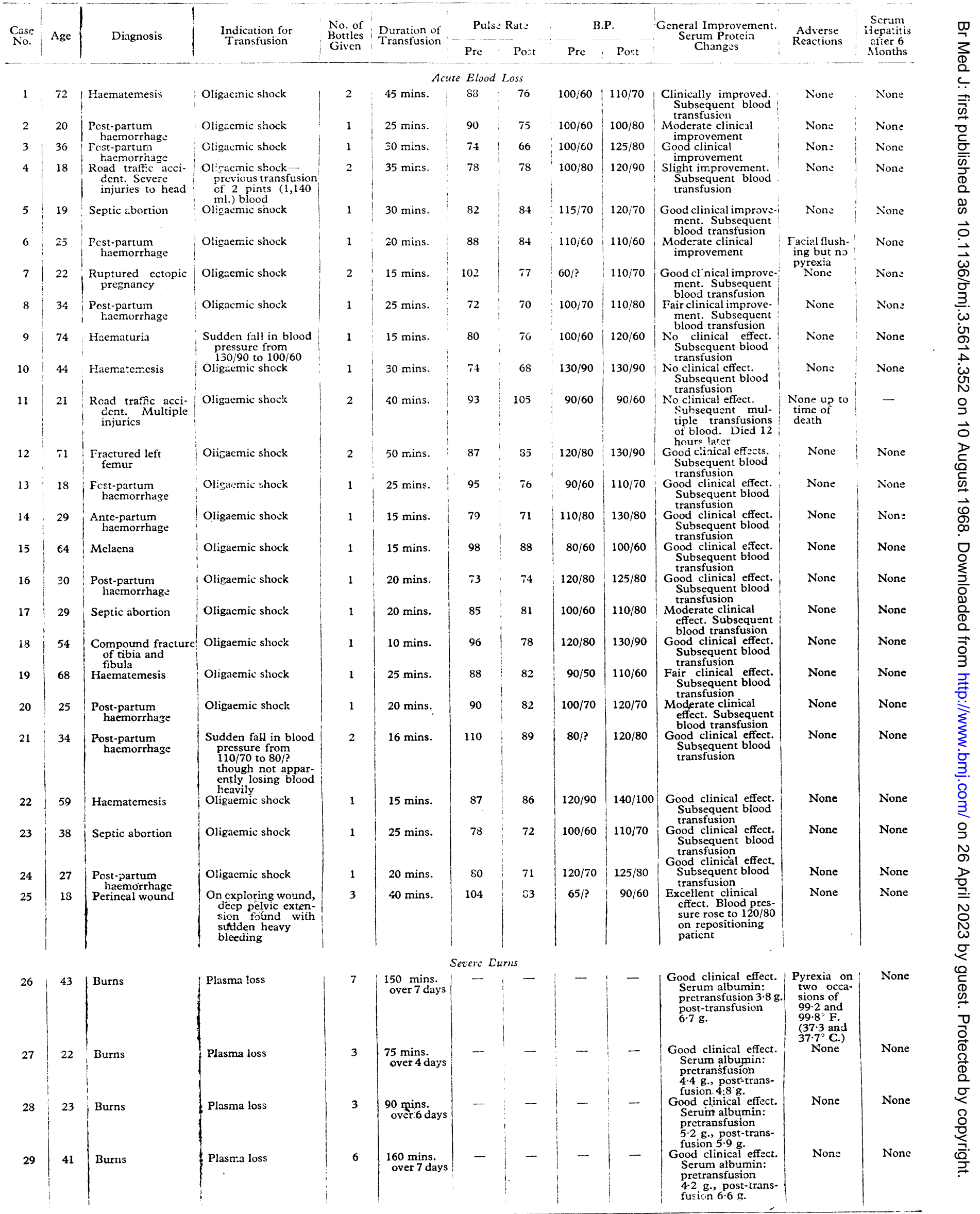


Details of Cases-continued

\begin{tabular}{|c|c|c|c|c|c|c|c|c|c|c|c|c|}
\hline \multirow{2}{*}{$\begin{array}{l}\text { Case } \\
\text { No. }\end{array}$} & \multirow{2}{*}{ Age } & \multirow{2}{*}{ Diagnosis } & \multirow{2}{*}{$\begin{array}{l}\text { Indication for } \\
\text { Transfusion }\end{array}$} & \multirow{2}{*}{$\begin{array}{l}\text { No. of } \\
\text { Bottles } \\
\text { Given }\end{array}$} & \multirow{2}{*}{$\begin{array}{l}\text { Duration of } \\
\text { Transfusion }\end{array}$} & \multicolumn{2}{|c|}{ Pulse Rate } & \multicolumn{2}{|c|}{ B.P. } & \multirow{2}{*}{$\begin{array}{c}\text { General Improvement. } \\
\text { Serum Protein } \\
\text { Changes }\end{array}$} & \multirow{2}{*}{$\begin{array}{c}\text { Adverse } \\
\text { Reactions }\end{array}$} & \multirow{2}{*}{$\begin{array}{l}\text { Serum } \\
\text { Hepatitis } \\
\text { after } 6 \\
\text { Months }\end{array}$} \\
\hline & & & & & & Pre & Post & Pre & Post & & & \\
\hline
\end{tabular}

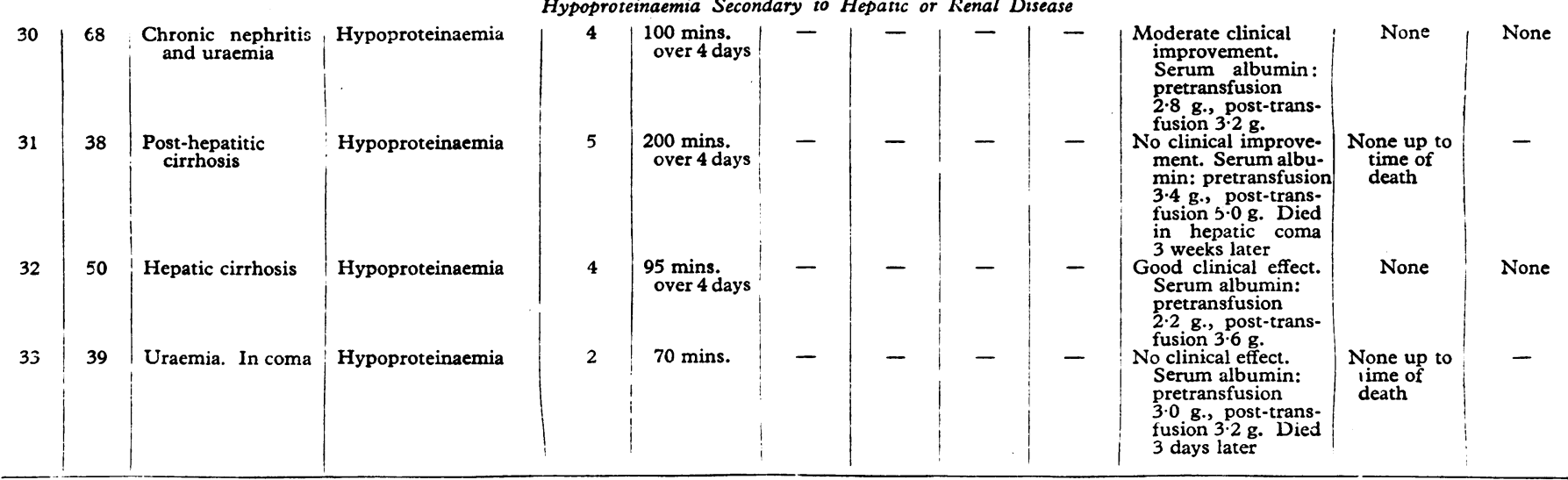

surfaces arrested but the serum albumin level actually rose in all cases. This was accompanied by a steady improvement in the clinical condition.

It is probable that any attempt to correct the hypoproteinaemia of cirrhosis must rely on the transfusion of amounts of albumin (cf. Dykes, 1961 ; Wilkinson and Sherlock, 1962) of the order of $50 \mathrm{~g}$. a week with a possible "loading" dose of $1,000 \mathrm{~g}$. Since each bottle of plasma protein solution contains approximately $14.5 \mathrm{~g}$. of albumin, a more concentrated albumin solution would be preferable for this purpose. Though one of our two patients showed improvement, no conclusions could be drawn from only two cases.

Little improvement was observed in two patients suffering from renal disease and hypoproteinaemia. It is unlikely that transfusion of plasma protein solution is of any lasting benefit in such cases.

\section{Adverse Effects}

Immediate adverse effects resulting from transfusion of plasma protein solution were minimal-one case of facial flushing and two instances of mild pyrexia in a patient receiving four transfusions. No urticarial rashes or more severe allergic manifestations occurred, and no delayed reactions were noted. This may be compared with an incidence of urticaria ranging from 1 to $3 \%$ in patients receiving plasma (DeGowin, Hardin, and Alsever, 1949 ; Stephen, Martin, and Bourgeois-Gavardin, 1955 ) and with the very occasional severe febrile reactions due to plasma described by Dameshek and Neber (1950).

No case of serum hepatitis occurred in the 30 patients checked six months after transfusion. Had a case of serum hepatitis come to light matters would have been complicated by the fact that most of these patients had also received transfusions of whole blood. However, since the heating of plasma to $60^{\circ} \mathrm{C}$. for 10 hours is known to inactivate the agent of serum hepatitis, any case that may occur must represent infection from some source other than the plasma protein solution.

\section{Conclusion}

The above findings indicate that plasma protein solution is a very acceptable substitute for reconstituted dried plasma. It possesses the great advantage that transfusion carries no risk of serum hepatitis. Plasma protein solution is probably most useful in the treatment of burns, when multiple transfusions of plasma protein must be given but where transfusion of whole blood is not often necessary. In cases of acute haemor- rhage whole blood transfusions are usually required in addition to a plasma expander, and a slight risk of infection with serum hepatitis is introduced (about $0.5 \%$ per two bottles of blood: Lehane, Kwantes, Upward, and Thomson, 1949 ; Medical Research Council, 1954). No accurate figures for the cost of a bottle of dried plasma are available for comparison.

Plasma protein solution possesses further advantages in the treatment of acute blood loss. Since it is made up as a solution which has a bench life of five years at room temperature, it can be easily stored at sites suitable for emergency, and can be transfused as soon as an intravenous drip has been set up. No time is wasted in reconstituting a dried product. Bottles of plasma protein solution could be kept in accident boxes, operating-theatres, and on anaesthetic-trolleys. The material would also be valuable for obstetrical flying squads.

A particular advantage of plasma protein solution over the majority of dextrans is that it does not cause rouleaux formation of the recipient's red blood cells (Salsbury, 1967). It can therefore be transfused in emergency before blood is taken for grouping and cross-matching.

We would like to thank Professor D. L. Mollin for reading the proofs and offering much good advice.

\section{REFERENCES}

Auerswald, W., and Doleschel, W. (1959). Bibl. haemat. (Basel), 9, 61. Auerswald, W., Doleschel, W., and Szegvári, G. (1959). Anaesthetist, 8, 106.

Auerswald, W., and Eibl, H. (1955). Wien. med. Wschr., 105, 298.

Cohn, E. J., et al. (1946). f. Amer. chem. Soc., 68, 459.

Dameshek, W., and Neber, J. (1950). Blood, 5, 129.

DeGowin, E. L., Hardin, R. C., and Alsever, J. B. (1949). Blood Transfusion. London.

Dykes, P. W. (1961). Quart. f. Med., 30, 297

Hillman, R. S. (1964). New Engl. F. Med., 271, 1027

Hutchison, J. L., Freedman, S. O., Richards, B. A., and Burgen, A. S. V. (1960). F. Lab. clin. Med., 56, 734

Lehane, D., Kwantes, C. M. S., Upward, M. G., and Thomson, D. R (1949). Brit. med. 7., 2, 572 .

Medical Research Council (1954). Lancet, 1, 1328.

Morgan, H. V., and Williamson, D. A. J. (1943). Brit. med. 7., 1, 750

Murray, R., and Diefenbach, W. C. L. (1953). Proc. Soc. exp. Biol. (N.Y.), 84, 230 .

Murray, R., Diefenbach, W. C. L., Geller, H., Leone, N. C., and Ratner, F. (1955). N.Y. St. F. Med., 55, 1145

Nitschmann, H., and Kistler, P." (1954) Helv. chim. Acta, 37, 1767.

Nitschmann, H., Kistler, P., Renfer, H. R., Hässig, A., and Joss, A (1956). Vox Sang. (Basel), 1, 183.

Nitschmann, H., Rickli, E., and Kistler, P. (1959). Helv. chim. Acta, 42, 2198.

Paine, R. S., and Janeway, C. A. (1952). f. Amer. med. Ass., 150, 199. Salsbury, A. J. (1967). Brit. med. $¥ ., 4,88$.

Stephen, C. R., Martin, R. C., and Bourgeois-Gavardin, M. (1955). F. Amer. med. Ass., $158,525$.

Wilkinson, P., and Sherlock, S. (1962). Lancet, 2, 1125. 